\title{
ROOT CAUSE ANALYSIS ON HOSPITAL STANDARDS AND JOINT COMMISSION INTERNATIONAL STANDARDS: A COMPARATIVE STUDY
}

\author{
Analisis Perbandingan antara Analisis Root Cause pada Standar Rumah Sakit dan \\ Standar Joint Commission International: Sebuah Studi Perbandingan
}

\author{
*Bella Putri Lanida1, Tito Yustiawan², Sylvy Medtasya Dzykryanka \\ ${ }^{1}$ Faculty of Public Health, Universitas Airlangga, Indonesia \\ ${ }^{2}$ Faculty of Public Health, Universitas Airlangga, Indonesia \\ ${ }^{3}$ Mother and Child Hospital of Kendangsari Merr, Indonesia \\ *Correspondence: bella.putri.lanida-2016@fkm.unair.ac.id
}

\begin{abstract}
Background: Healthcare Associated Infections (HAls) are infections that patients caught during medical treatment and health care. Prevention and control of infection will lead to patient safety, which ultimately has an impact on efficiency, management of health care facilities, and improvement of service quality. Infection can be controlled by identifying the causes. One method to achieve this goal is the Root Cause Analysis (RCA).

Aim: This study aims to analyze the implementation of Root Couse Analysis (RCA) conducted by the Infection Prevention and Control Committee at the Mother and Child Hospital of Kendangsari MERR Surabaya.

Method: This is a quantitative observational research that utilizes descriptive data analysis. This study is a cross sectional study and its results are presented narratively.

Results: Results show that the Joint Commission International Standard 2015 version of RCA was not fully implemented at the Mother and Child Hospital of Kendangsari MERR Surabaya. Some methods, such as the fishbone and Plan-Do-Study-Action (PDSA), were not implemented. Limited resources became the contributing factor.

Conclusion: Infection Prevention and Control Committee at the Mother and Child Hospital of Kendangsari Merr Surabaya has implemented 9 out of 21 RCA steps of the Joint Commission International Standard 2015. The hospital needs to use other methods as an addition to the 5 Why's in implementing RCA, such as fishbone diagrams and Plan-Do-Study-Action (PDSA), for problem solving planning.
\end{abstract}

Keywords: Root Cause Analysis (RCA), HAls, Infection prevention and control.

\section{ABSTRAK}

Latar Belakang: HAls adalah infeksi yang terjadi pada pasien ketika menerima perawatan dan pelayanan kesehatan. Pencegahan dan pengendalian infeksi akan mewujudkan adanya patient safety yang pada akhirnya berdampak pada efisiensi, manajemen fasilitas pelayanan kesehatan dan peningkatan kualitas pelayanan. Insiden infeksi yang terjadi harus dikendalikan dengan melakukan indetifikasi sampai ditemukananya penyebab dari peristiwa atau masalah tersebut. Sehingga suatu organisasi dapat menggunakan teknik Root Cause Analysis atau RCA yang dapat diaplikasikan untuk mengatasi kondisi tersebut.

Tujuan: Penelitian ini bertujuan melakukan analisis terhadap proses pelaksanaan Root Couse Analysis (RCA) di Komite PPI RSIA Kendangsari Merr Surabaya.

Metode: Jenis penelitian ini adalah observasional dengan analisis data deskriptif pendekatan kuantitatif karena hasil penelitian disampaikan secara naratif. Ditinjau dari segi waktu penelitian termasuk penelitian cross sectional.

Hasil: Hasil analisis kesesuaian tahapan RCA yang ada pada Joint Commission International Tahun 2015 dengan pelaksanaan RCA di Komite PPI RSIA Kendangsari Merr tidak semua dilakukan oleh Komite PPI.Hal tersebut disebabkan karena kurangnya applikasi metode lain seperti fishbone dan metode Plan-Do-StudyAction (PDSA), serta terdapat kerterbatasan sumber daya yang dimiliki oleh RSIA Kendangsari Merr Surabaya. Kesimpulan: Komite PPI RSIA Kendangsari Merr Surabaya telah melakukan 9 langkah RCA dari 21 langkah yang ada pada standar Joint Commission International Tahun 2015. Rekomendasi untuk rumah sakit adalah menggunakan metode lain selain dari the 5 why dalam pelaksanaan RCA seperti diagram fishbone dan metode Plan-Do-Study-Action (PDSA) untuk perencanaan pemecahan masalah.

Kata Kunci: Root Cause Analysis (RCA), HAls, Pencegahan dan pengendalian infeksi. 


\section{INTRODUCTION}

Infectious disease is one of health problems in various countries in the world, including Indonesia. Issues of infectious diseases has been frequently bought up in various international forums, such as the Asian Pacific Economic Committee (APEC) and the Global Health Security Agenda (GHSA). Healthcare Associated Infections (HAls), for instance, have a direct impact to the country's economic expenses (Ministry of Health of the Republic of Indonesia, 2017). HAls are infections that patients get when they receive medical treatment and health care. HAls are caused by infectious agents, including bacteria, fungi, viruses, and other types of pathogens (Almeida, 2015). HAls are a significant cause of morbidity and mortality on patients receiving health care, and the direct and indirect costs of these infections use up limited financial resources allocated to health service delivery (Nazir and Kadri, 2014).

In 2007, the Centers for Disease Control (CDC) and Healthcare Infection Control Practices Advisory Committee (HICPAC) recommended 11 main components that must be implemented and adhered to as standard precautions. The 11 main components are hand hygiene, personal protective equipment (PPE), decontamination of patient care equipment, environmental health, waste management, linen management, health care workers' protection, patient placement, respiratory hygiene/ethics of coughing and sneezing, safe injecting practices, and safe practice of lumbar puncture (Ministry of Health of the Republic of Indonesia, 2017).

Infection prevention and control programs can be carried out in health facilities as a solution to prevent HAls. According to Nazir and Kadri (2014), hospital infection control programs can prevent 33\% of nosocomial infections. The main goal of an infection control program is to reduce the risk of infection during the hospitalization period. Based on the Regulation of Minister of Health of Republic of Indonesia No. 27 Year 2017, Infection Prevention and Control (IPC) is an effort to prevent and minimize the occurrence of infections in patients, officers, visitors, and the community surrounding health care facilities.

One of the infection prevention and control activities is the implementation of risk grading in response to occurence of infection. Risk grading aims to separate the risk of unacceptable infections from the risk of tolerable infection. These risks must be evaluated consistently. Risks are usually analyzed by combining estimated consequences (also described as a severity or an outcome) and possibilities (frequency or probability) in the context of existing control measures (Dumbrava and lacob, 2013). Based on the Regulation of Minister of Health of Republic of Indonesia No. 27 Year 2017, calculating risk value, or risk grading, is useful to determine the next steps to be taken, namely a simple investigation or Root Cause Analysis (RCA). Infection Prevention and Control will protect the community and establish patient safety, which in turn has an impact on the efficiency of health care facilities management and improvement of service quality. The Mother and Child Hospital of Kendangsari MERR Surabaya is one of the private hospitals specifically aimed to provide health services to mothers and children, ranging from basic, specialistic, and subspecialistic health services.

The changes of infectious disease patterns at the hospital and shifts of economic risks require systematic efforts of infection control. This means that the Infection Prevention and Control Committee and trained professionals have to be able to collect data and run education and consultation programs, as well as integrated infection prevention and control measures. Taking this into consideration, this study aims to analyze the implementation of Root Cause Analysis (RCA) at the Mother and Child Hospital of Kendangsari MERR Surabaya as part of infection prevention and control efforts.

\section{METHOD}

This is an observational research in which data collection was done through observation without any treatment to the object. This study uses descriptive data analysis with quantitative approach because the results of the study are delivered in narration. In regard of time of the research, this is a cross-sectional research because the variables are measured and observed at the same particular time. The study was conducted at the Mother and Child Hospital of Kendangsari MERR Surabaya, especially at its Infection Prevention and Control (IPC). The study took place from August 2018 to September 2018 utilizing in-depth interviews and document observation, as an addition to observation, for the data collection. Primary data were obtained from in-depth interviews with members of the committee, and secondary data were obtained from documents owned by the committee. Data collected were then analyzed using content analysis method by comparing the results of research with literature review.

\section{RESULTS AND DISCUSSION}

HAls can actually be prevented if health facilities carry out infection prevention and control. The nosocomial infection prevention requires an integrated program that can be monitored by involving its main components (Nazir and Kadri, 2014). Prevention and control are done to minimize the infection risk of officers, visitors, and communities surrounding the health care facilities by establishing a particular committee at the hospital. It is in compliance with the Regulation of Minister of Health of Republic of Indonesia No. 27 Year 2017 about Infection Prevention and Control, hereinafter abbreviated as IPC.

\section{Composition of IPC Committee}

Table 1 explains the results of document review regarding the committees of infection prevention and control at the Mother and Child Hospital of Kendangsari MERR Surabaya. 
Table 1. Committee Structures.

\begin{tabular}{lc}
\hline Position & $\mathbf{n}$ \\
\hline Committee chairman & 1 \\
Committee secretary & 1 \\
Infection Prevention Control & 1 \\
$\begin{array}{l}\text { Member (IPCM) } \\
\text { Infection Prevention Control Nurse }\end{array}$ & 1 \\
(IPCN) & \\
Infection Prevention Control Link & 7 \\
Nurse (IPCLN) & 8 \\
Infection Control (IC) & 17 \\
\hline $\mathbf{n}$ &
\end{tabular}

Source: Data from Comittee of Prevention and Control of Infection at the Mother and Child Hospital of Kendangsari MERR Surabaya

It can be seen from the table that IPCLN has seven members from different units, such as inpatient nurses, Verlos Kamer (VK), baby room, outpatient installation, Emergency Room Installation, Operating Room and Neonatal Intensive Care Unit (NICU). Meanwhile, IC has eight members consisting of laboratory units, pharmacy, Central Sterile Supply Department (CSSD), environmental and household health, morgue, hospital facilitiy maintenance unit, nutrition, and medical records. Based on the suitability analysis of human resources and according to the Regulation of Minister of Health Regulation No. 27 of 2017, the personnel allocation has met the requirements. Nevertheless, there are still weaknesses in terms of double allocation, for instance the position of chairman in the IPC and IPCO is carried out by the same person in the Secretary and IPCN.

\section{Standard Operating Procedures of Infection Prevention and Control}

The U.S Environment Protection Agency and the European Medicines Agency define Standard Operating Procedures (SOP) as a series of detailed written instructions or document routines or activities in an organization to achieve the uniform performance of a particular function. Based on indepth interviews conducted with IPCN and review of documents on the types of SOP in the infection prevention and control, there was no SOP for RCA. Results of conformity analysis based on the Regulation of Minister of Health No. 27 Year 2017 show that the types of SOP used by the committee were in compliance. However, the committee did not have SOP for health employees or protection for health workers.

SOP sheet format prepared by IPC Committee at the Mother and Child Hospital of Kendangsari MERR Surabaya was in accordance with the format issued by the United States Environmental Protection Agency (2007), but there were several inappropriate formats. First, the SOP covered types of division, types of data, and reports produced in carrying out the procedures. Second, the method of quality control was used to demonstrate the performance success. Third, the bibliography was used as a guideline for formulating the SOP.

Implementation of Root Cause Analysis (RCA)

Root Cause Analysis (RCA) is a systematic and causal analysis that focuses on finding the lowest failure rate. However, there are three constraints in implementing the process. First, lots methods and tools of RCA are complex and difficult to use. Second, many RCA methods or tools require special softwares resulting in limited access and significant amount of initial capital investment. Finally, some methods or tools also require adherence to very rigid structures that limit creativity and risk possible loss of the true root causes (York et al., 2014).

Root Cause Analysis is known to be a reactive approach because it is identified after a problem arises. RCA identifies all system failures, humans, or combinations of both that cause problems. The benefits of comprehensive RCA include the identification of permanent solutions, prevention of failure recurrence, and introduction of logical problem-solving processes which apply to problems and misconducts of all sizes (Bhattacharya, 2014). The results from in-depth interviews and document observations regarding RCA implementation at the Mother and Child Hospital of Kendangsari MERR Surabaya were then analyzed with $21 \mathrm{RCA}$ steps issued by the 5th Edition of the Joint Commission International (Buczkowski et al., 2015).

\section{Organize a team}

Root Cause Analysis process must starts first with forming a team that consists of members from all layers of staffs who have basic knowledge of the specific areas involved (Shaqdan et al., 2014). The IPC Committee at the Mother and Child Hospital of Kendangsari MERR Surabaya has established its own team to conduct RCA. The team consists of one person as team leader, another one as secretary, and six people as members of various units involved. The number of RCA team members at the hospital is in accordance with the statement of Charles et al. (2016) which says that the team must consist of four to six doctors, supervisors, and quality improvement experts with basic knowledge of certain areas of interest.

\section{Define the problem}

The second process in responding to problems is by defining the problem or incident that occurred. A good definition is done when describing what is wrong and focusing on results, not why the results occur. Based on the interview with the Infection Prevention and Control Nurse (IPCN), the RCA team conducts meetings to discuss about infectious incidents that occurred. However, document review yields no result on any record of definitions as why the infection occurred.

\section{Study the problem}

The third process is collecting information about the incident that the team can use as a starting point. The Mother and Child Hospital of Kendangsari MERR Surabaya, based on the document review, has collected information, such as statements from and observations of the people closest to the problem, as well as those who were 
indirectly involved such as doctors, nurses, operating room personnel, and clinic personnel. IPC Committee also has evidence in the form of photos as documentary evidence, documents from medical records, operating room registration, tool usage schedule, service schedule, results of tool swabs, and other laboratory results.

\section{Determine what happened}

The fourth process is to designate the problem by asking $5 \mathrm{~W} 1 \mathrm{H}$ questions that are important and relevant to the incident (Shaqdan et al., 2014). Mother and Child Hospital of Kendangsari MERR Surabaya has carried out this fourth stage. This is evidenced from the results of interviews with the officers involved and from the chronology table or tabular timeline that has been made by IPCN. According to Nicolini, Waring and Mengis (2011), the first major challenge for RCA investigation is gathering information and evidence. After the reported incident has been assessed and investigated, RCA directs the company's manager or local patient safety leader to be responsible for collecting more detailed information that serves to strengthen the report contents and to gather evidence about actions against the problem.

\section{Identify contributing process and factors}

At this stage, IPC Committee carries out the identification process of activities involved. The RCA can be executed using various tools in determining the cause of the problem, such as the analysis of 5 WHYs, fishbone, causal diagrams, and pareto charts (Shaqdan et al., 2014). The Mother and Child Hospital of Kendangsari MERR Surabaya, based on the document review, has carried out the fifth stage using the 5 WHYs, but this has not been able to be used to answer the questions about the process and relevant factors.

\section{Identify other contributing factors}

The next step is to determine the contributing factors beyond the process which consist of human factors, equipment factors, and factors related to information, as well as controlled or uncontrolled environmental factors. Fishbone diagrams can help to highlight many factors involved in an incident. Based on the document review, the Mother and Child Hospital of Kendangsari MERR Surabaya has not done this step because it only uses the 5 WHYs method.

\section{Measure-collect and assess data on proximate and underlying causes}

Data collection is combined to determine incident indicators. Joint Commission International 2015 stated that measure is a process of collecting and merging data. This process helps to assess the level of performance, determine whether corrective action is needed, and ensure whether improvements have occurred. At the Mother and Child Hospital of Kendangsari MERR Surabaya, based on the document review, there were indicators or work targets for the infection insidents that occurred, such as the number of infections per month, three months, semester, and year. One example of work targets is the one for surgical site infection at the Mother and Child Hospital of Kendangsari MERR Surabaya which value is set to be $\leq 2 \%$.

\section{Design and implement immediate changes}

The Joint Commission International 2015 stated that health care in problematic situation can cause potentially serious results that may endanger the patient. Thus, a quick solution or first treatment may be needed temporarily to alleviate the problem while the team will continue to work to find the root cause. The Mother and Child Hospital of Kendangsari MERR Surabaya, based on the document review, has taken a temporary action to overcome incidents by immediately swabing the device when the infection occured.

\section{Identify which systems are involved in the root causes}

The next step is to identify the hospital system involved in the root cause. The system factors are categorized according to organizational functions or processes carried out by the organization. These processes involve human resources, information management, environmental management, leadership and organizational culture, and encouragement of communication and clear priority communication. The Joint Commission International 2015 stated that fishbone diagram is very helpful in categorizing and visualizing various systems or problems that have contributed to the incidents. Categories within this diagram include people, procedures, equipment or materials, environment, and policies. The Mother and Child Hospital of Kendangsari MERR Surabaya, based on the document review, has not applied fishbone diagram method.

\section{Prune the list of root causes}

The Joint Commission International 2015 stated that if the causal factors have been determined, each cause must be analyzed using logic-based reasoning skills to determine the main cause. The IPC Committee has not clearly stated which was the main cause of the incidents because they do not have the list of factors that cause the incidents. It happened because the IPC Committee only used the $5 \mathrm{MHYs}$ method, so the factors cannot be comprehensively found.

\section{Confirm root causes and consider their interrelationships}

The cause of the incident or root problem usually consists of more than one cause. The Mother and Child Hospital of Kendangsari MERR Surabaya, based on the document review, already has a document listing the incident causes. Infection incidents at The Mother and Child Hospital of Kendangsari MERR Surabaya had three problem root causes from three different factors.

\section{Explore and identify risk reduction strategies}

The next step is to identify the improvement steps and risk reduction strategies. After identifying the main causes of the incidents, the identification of improvement measures and risk reduction strategies can be done using various techniques to 
achieve potential action plans. The Mother and Child Hospital of Kendangsari MERR Surabaya has not implemented risk reduction. Therefore, risk reduction can be done using one of the methods mentioned by the 2015 Joint Commission International, namely Failure Mode and Effects Analysis (FMEA).

FMEA is a systematic and prospectively proactive method used to identify and understand the contributing factors involved in the failure of a process, system, or method. In addition, this method can be used as an active tool to improve patient safety and hospital efficiency. The method determines the vulnerable and critical elements of a system (Shebl, Franklin and Barber, 2012).

\section{Formulate improvement actions}

The measure of success can be determined from trial activities that are carried out. The Mother and Child Hospital of Kendangsari MERR Surabaya has not yet identified the measure of its success. The scientific method of Joint Commission International 2015, such as plan, do, study, act cycle, can be proposed to find the measure of success. This method allows the team to test how successful changes have been made and whether they need to be improved, and other experiments if no good results are achieved.

\section{Evaluate the proposed improvement actions}

The evaluation process is done by comparing plans with internal references, SOPs, and external practices and standards to help the final action plan executed well.

\section{Design improvements}

Design improvement is an action plan that identifies the strategies to be implemented in order to reduce the risk of similar incidents occurring in the future. The Joint Commission International 2015 mentioned the plan must address five issues about what, how, when, who and where are the implementation and evaluation of the effective and corrective actions. The Mother and Child Hospital of Kendangsari MERR Surabaya, based on the document review, had the documents of the recommendation forms and the action plans for the incidents.

\section{Ensure the acceptability of the action plan}

The step is taken to ensure the action plan is acceptable. The document review found that the Mother and Child Hospital of Kendangsari MERR Surabaya has not implemented the step to ensure the acceptance of the action plan.

\section{Develop Measures of Effectiveness and Ensure Their Success}

If the function is in progress, the team must collect data about its performance. The Joint Commission International 2015 stated that measurement is a process of collecting and combining data to assess the level of performance and determine whether further corrective action is needed. Particularly, measurements can be used as integral techniques throughout Plan-Do-StudyAction (PDSA) cycle.

\section{Evaluate the Implementation of Improvement Efforts}

The next stage is done using the data collected as a part of the measurement. The data must be translated into information to make an assessment and draw conclusions about the performance of the improvement efforts. This assessment forms a basis for further action taken with the improvement initiatives. Many techniques can be used to assess the data. Most types of assessments require comparing data to a reference point.

\section{Take additional action}

The team's assessment of the data shows whether or not the targets have been achieved. This stage is related to the set targets of the action plan that has been tested and implemented. If the objectives are achieved, the team must now focus on communication, standardization, and introduction of successful improvement initiatives.

\section{Communicate the results}

The RCA results must be communicated to all staff members involved and the management. It is very important to build trust and appreciation for the team in this process. A table can be made to list the causes, identification of root causes, and recommendations to everyone. The RCA process is based on Joint Commission International standards, but there are steps that have not been implemented by the Mother and Child Hospital of Kendangsari MERR Surabaya due to the ommission of other methods, such as fishbone and PDSA. Moreover, there are limitation of available resources, one of which is that most IPC committee members have not received training about RCA. The committee can work with the team of Patient Safety Quality Control (PSQC) at the hospital for the implementation of RCA because PSQC team has received RCA special training. The following methods are suggested to be applied for the implementation of RCA (Brook et al., 2015).

First is Pareto analysis. This is an easy-touse technique that helps user choose the most effective changes to do. The Pareto principle mentions the idea of doing $20 \%$ of your work can generate $80 \%$ of your profit in doing the whole job. Pareto analysis is a formal technique for finding changes that will yield the greatest benefits.

Second, Osborn suggests that groups can double their creative results with brainstorming. Brainstorming works by focusing on the problem, and subsequently formulate as many solutions as possible and develop them as far as possible. Using brainstorming refers to the process of generating new ideas or solving problems so that the goal is to identify not only the most obvious root causes, but also the possible underlying problems.

Third is the 5 WHYs. This is the simplest method for structured RCA. This is a method of asking questions which later be used to explore the causes underlying the problem. The investigator continues asking the question 'Why?' until a meaningful conclusion is reached. General recommendation is that the investigator asks the questions at least five times, although sometimes 
additional questions are also needed to ensure that the real cause is identified.

The fourth method is fishbone diagram. The purpose of describing a problem in a diagram or image is to easily understand the description and the factors of the problem in one diagram or image. The basic concept of a fishbone diagram is a fundamental problem placed on the right side of the diagram or in the head part of the fishbone skeleton. The cause of the problem is described on the fins and bones. The main factors of the problem can be assessed in fishbone diagrams using the $6 \mathrm{Ms}$ (Materials, Methods, Mechanisms, Machines, Money, and Manpower) or 4P (Parts (raw materials), Procedures, Plants (equipment), and People). However, the categories can also be selfdetermined based on individual problem. The causes of such problem can be looked into in more detais by looking for the identified causes. The detailed causes can be obtained using the "5WHYs" method in interviews and focus group discussion.

Fifth method is the Fault Tree Analysis (FTA), which is a quantitative causal diagram used to identify possible failures in a system. This is a general technical tool used in the design phase of a project and the identification of possible causal relationships. The fault tree has a parallel and sequential combination of errors that will produce a predetermined unfavorable incident. Errors can be associated with human errors or other incidents, so the fault tree describes a logical reciprocal relationship from a basic incident that leads to an unwanted incident which is a faulty treetop incident (Wessiani and Yoshio, 2017).

Sixth is the PDSA method which is derived from industry and Walter Shewhart. Edward Deming articulated a repetitive process finally known as the four stages of PDSA. PDCA (Plan - Do - Check Act) improves the quality and safety of health services. In recent years, the Quality Improvement methods (QI), such as the Plan-Do-Study-Action (PDSA) cycle, have been used to encourage improvement. This method is widely used for improving health care, but there is little overall evaluation of how this method is applied (Taylor et al., 2014).

\section{CONCLUSION}

The results of RCA at the Mother and Child Hospital of Kendangsari MERR Surabaya indicate that out of 21 steps in the 2015 Joint Commission International, nine steps were taken by the IPC Committee at the hospital. The other 12 steps were not carried out. The Mother and Child Hospital of Kendangsari MERR Surabaya should make SOP for RCA implementation and encourage members of the committee to join basic Infection Prevention and Control and RCA training.

\section{CONFLICT OF INTEREST}

The authors declare that they have no conflict of interests.

Almeida, S.-L. (2015) 'Health Care-Associated Infections (HAls)', Journal of Emergency Nursing. Emergency Nurses Association, 41(2), pp. 100-101. doi: 10.1016/j.jen.2015.01.006.

Bhattacharya, J. (2014) 'Root Cause Analysis - A Practice to Understanding and Control the Failure Management in Manufacturing Industry', International Journal of Business and Management Invention, 3(10), pp. 1220.

Brook, O. R. et al. (2015) 'Root Cause Analysis: Learning from Adverse Safety Events', RadioGraphics, 35(6), pp. 1655-1667. doi: 10.1148/rg.2015150067.

Buczkowski, L. et al. (2015) Root Cause Analysis in Health Care: Tools and Techniques. 5th edn. Edited by J. Parker. United States of America: Joint Commission International. Available at: https://www.jcrinc.com/assets/1/14/EBRCA1 5Sample.pdf.

Charles, R. et al. (2016) 'How to perform a root cause analysis for workup and future prevention of medical errors: A review', Patient Safety in Surgery. Patient Safety in Surgery, pp. 1-5. doi: 10.1186/s13037-0160107-8.

Dumbrava, V. and lacob, V.-S. (2013) 'Using Probability - Impact Matrix in Analysis and Risk Assessment Projects', Journal of Knowledge Management, Economics and Information Technology, Special Is, pp. 7696. doi: 10.1039/b815978e.

Ministry of Health of the Republic of Indonesia (2017) Pedoman Pencegahan dan Pengendalian Infeksi di Fasilitas Pelayanan Kesehatan. Indonesia: Peraturan Menteri Kesehatan Republik Indonesia. Available at: http://ditjenpp.kemenkumham.go.id/arsip/bn/ 2017/bn857-2017.pdf.

Nazir, A. and Kadri, S. (2014) 'An overview of hospital acquired infections and the role of the microbiology laboratory', International Journal of Research in Medical Sciences, 2(1), pp. 21-27. doi: 10.5455/2320$6012 . i j r m s 20140205$.

Nicolini, D., Waring, J. and Mengis, J. (2011) 'Policy and practice in the use of root cause analysis to investigate clinical adverse events: Mind the gap', Social Science and Medicine. Elsevier Ltd, 73(2), pp. 217-225. doi: 10.1016/j.socscimed.2011.05.010.

Shaqdan, K. et al. (2014) 'Root-cause analysis and health failure mode and effect analysis: Two leading techniques in health care quality assessment', Journal of the American College of Radiology. Elsevier Inc, 11(6), pp. 572-579. doi: 10.1016/j.jacr.2013.10.024.

Shebl, N. A., Franklin, B. D. and Barber, N. (2012) 'Failure mode and effects analysis outputs: are they valid?', BMC Health Services Research, 12(150), pp. 1-10. doi: 10.1186/1472-6963-12-150.

Taylor, M. J. et al. (2014) 'Systematic review of the 
application of the plan-do-study-act method to improve quality in healthcare', BMJ Quality and Safety, 23(4), pp. 290-298. doi: 10.1136/bmjqs-2013-001862.

United States Environmental Protection Agency (2007) Guidance for Preparing Standard Operating Procedures (SOPs). Washington.

Wessiani, N. A. and Yoshio, F. (2017) 'Failure mode effect analysis and fault tree analysis as a combined methodology in risk management', in IOP Conference Series: Materials Science and Engineering. United Kingdom: IOP. doi: 10.1088/1757-899X/337/1/012033.

York, D. et al. (2014) 'Practical Root Cause Analysis Using Cause Mapping', in Proceedings of the International MultiConference of Engineers and Computer Scientists. Hong Kong: International Association of Engineers. Available at: http://www.iaeng.org/publication/IMECS2014 /IMECS2014_pp985-989.pdf. 